\title{
A!
}

This is an electronic reprint of the original article.

This reprint may differ from the original in pagination and typographic detail.

Knight, John

\section{Economies of Design by Guy Julier}

Published in:

The Design Journal

DOI:

$10.1080 / 14606925.2019 .1562776$

Published: 22/02/2019

Document Version

Peer reviewed version

Please cite the original version:

Knight, J. (2019). Economies of Design by Guy Julier: Book Review. The Design Journal, 22(1), 115 - 120. [1].

https://doi.org/10.1080/14606925.2019.1562776

This material is protected by copyright and other intellectual property rights, and duplication or sale of all or part of any of the repository collections is not permitted, except that material may be duplicated by you for your research use or educational purposes in electronic or print form. You must obtain permission for any other use. Electronic or print copies may not be offered, whether for sale or otherwise to anyone who is not an authorised user. 


\section{BOOK REVIEW}

Economies of Design by Guy Julier,

London: Sage Publishing, 2017, 224 pages

Paperback ISBN: $9781473918863 £ 26.99$

This book is a potent mix of theory, insights, reflections and, as you might expect from the title, includes a smattering of charts, tables and data too. At a diminutive 224 pages, it's a compact, hasty tempered read, that takes us through a whistle-stop tour of economics and design. Pretty much everyone knows author Guy Julier's credentials as a pioneering academic and solid commentator on design. In his latest book, he extends his portfolio collecting rich, diverse and voluminous source material that he puts to the service of bestselling academic publishing.

A solidly crafted piece of writing, the author's skills in demystifying complexity have been universally recognized by pretty much anyone who has skimmed through it and particularly within the design community. The book is much more than a compilation. The author systematically stitches together all of the information he has uncovered into a wholly original and ground-breaking manifesto, that promulgates the idea that economic context and design are tightly coupled.

The writing is fluid; popping with quirky references, clever intuitions, snapshots and personal asides that pepper the storyline and hammer home the message of design and economics union. Rapid turns of thought, clever, surprising angles and insightful pauses underpin the solid writing and deliver a winning formula that was first applied to mixing culture and design. Julier's most recent publication stands shoulder to shoulder with that heady cocktail; 'Cultures of Design'. Both of these works conclude similarly too - putting 
flesh on good ideas will certainly keep Julier's acolytes busy, as there is much to develop from the kernel of expansive thoughts.

Analytical brilliance aside, the economies of design, is neither dry, bitter or overpowering, and certainly persuasive for an academic work. A sense of urgency pervades, in the beat of the prose and the choppiness feels as if Julier is cajoling readers to move on to the next dazzling point of departure; rather than losing them in the detail. The scattergun approach makes for a good read, but in some cases leaves loose ends, where undeveloped ideas and wobbly connections offer diminishing returns. Something the next edition must address.

The introduction compares 'the economy' as a 'singular concept' compared to design, which is 'too variegated in its practices, too widely deployed in how it is understood and used for us to enable singular definitions' ( $\mathrm{pp} 2$ ). The introduction to neoliberalism is a primer that frames this virulent form of late capitalism as a watershed against Keynesian state control. Neoliberalism is the book's 'big idea' and Julier assigns everything (including design) to its pervasive wretchedness. The book goes on to trace the ascent of free market thinking and doing, from its early post-war beginnings, through the cold war and onto big time global hegemony. Strange, that this once minority strand in economic theory, suddenly flowers, after Hayek, The Mont Pelerin Society and (other reactionary forces) into the realpolitik of Pinochet, Thatcher, Reagan and more recently Macron. Calling on 'Marxist Geographer' (pp 8) David Harvey considers neoliberalism as:

proposing 'that ...human wellbeing can best be advanced by liberating individual entrepreneurial freedoms and skills within an institutional framework characterized by strong private property rights, free markets and free trade.' 
This overarching 'theory of political economic practices' (ibid) is further elaborated as 'liberal concepts that include deregulation, financialization, austerity and the 'New Economy' ${ }^{\mathrm{i}}$ or the internet as we know it more commonly. This is a very liberal, progressive account where the economic grunt work is a relatively easy to grasp and the financial levers are relatively familiar concepts. At the micro level, neoliberalism is a tougher call.

Comprehending it as reified behaviour is a tough going and necessitates readers to conceive economics as some kind of cognitive class DNA that controls every fibre of our being. To paraphrase neoliberalist critic, Ralph Fevre ${ }^{\text {ii }}$, the neoliberal:

'achieve(s) self-actualisation through the market rather than engaging in projects to change society...With a restricted political realm...businesses and organisations have taken increasing responsibility for the welfare and aspirations of individuals, embracing the neoliberal ideal. This takes several forms, including the delegation of responsibility and 'autonomy' to employees. While this sounds progressive... this leaves employees with the responsibility to ensure business success. As a result, they end up disciplining themselves...., and employers increasingly take responsibility for the health of workers, including their mental wellbeing.'

Unlocking neoliberalism's capacity as an all-encompassing worldview hinges on buying into it as hegemony. Oddly this plays out in TV's 'Changing Rooms' (pp 81 to 86) and 'the mall' (pp 86 to 95) as they are part of that conspiracy too. Readers are encouraged to suppose that: 'The state... is not telling neoliberal citizens how to live. Instead, 'experts' are distributed across such institutions as...the media... and they relay 'advice' on how lifestyles are carried out (Ouelette and Hay 2009, cited by Julier ibi). If that sounds Orwellian, so be it but recognising the totalizing effect of the economy is contingent on understanding the importance of the book and maybe even recharging our disciplines progressive agenda. 
Julier argues 'the rise of design and neoliberalism are connected' (pp 1). Of course, it doesn't take a financial whizz kid to wager that general economic growth feeds the creative classes and keeps them in sticky notes. A trickier bet is on whether the global economy's steady growth and eastward shift in the last thirty years ${ }^{\mathrm{iii}}$ fully supports Julier's analysis. Again, the drive to finalize, in some cases has an intuitive rightness but less so elsewhere. For example, the links made between economic downturn and rise of 'participatory design methods for social innovation' is uncontroversial. Other couplings are flaky, flimsy and occasionally arbitrary. Ergo, linking financialization to 'product detailing driven by shareholder value' seems a tall order to take on face value, let alone evidence it in theory building.

The second chapter moves from definition to 'Design Culture and the Neoliberal Object'. In terms of thingness, the neoliberalist article is inherently mutable and surely as much a product of digitalisation as right-wing political economy. At sixteen pages, the brevity of this section is a challenge. The average design masters student will baulk at the fragility of the argumentation. This important, strategic bridging chapter should detail out how economics and design incontrovertibly play out in practice. Unfortunately, the gaps are more than cosmetic and include: omitting Participatory Design from the analysis. Perhaps this strand of design's straightforward social democratic values lacks intellectual appeal. But our Scandinavian lethal weapon is vital in our fight for utopia. Dunne's anodyne dystopian reaction to capitalist decadence is useful in this fight too and equally ignored in the analysis. Even if these creative noodlings are trivial in the greater scheme of things, omitting groundup responses to politics diminishes design to merely following the hidden hand of economics and downplays a great deal of our community's values.

Julier dates the 1980s as the coronation of design and neoliberalism. Ad Age labels this neoliberal heyday as the 'decade of the deal' ${ }^{i v}$, when investors eye watering spends on 
agency mergers and acquisitions mirrored Wall Street moves. Advertising's consolidation put many of those ad mad men on welfare and reconstituted a new 'creative' class of bottom-line hugging hipsters. Nevertheless, the numbers tell their own tale and by 1990 only a third of advertising were independent compared to the previous decade. The traditional independent 'creative' agency's fall was a gain for a clique of 'interactive' monikered agencies (e.g. IDEO, Sapient and LBI) that would take over the world and, be omitted from the Economies of Design.

Broadening design's economic footprint beyond ads, brand and marketing, these embryonic experience engineers were cultivated by the 'tech' sector's cash. Few people at this time had the vision, drive and investment to push the design and technology complex to the max. Except Steve Jobs. The advertising legacy hampered broader exploitation of Apple's formula and is exemplified by The Dot com bubble ${ }^{\mathrm{v}}$ where marketing frenzy crashed against cognitive overload. Ben Elliot, recalls a time where:

'Design excesses were committed at a time when the Creative Economy was a fashionable notion, and as a consequence, creativity was fetishized and sorely misunderstood. Speaking as somebody who worked for a web design agency in the late 1990s, I can vouch for the fact that, at the time, thinking inside-the-box was virtually a sackable offence.'

The resulting downturn heralded venture capital's love affair with the tech start-up scene, where consistently high performing 'design-led' companies led stock price and boutique interactive agencies were gobbled up by global technology consultancies. Today any top ten 'agencies' list includes a good spread of those owned by global tech corporations such Accenture and IBM. 
Julier's wish to avoid 'technologically deterministic' (pp32) is a difficult stance in an era of rapid, deep and broad digital transformation. When Amazon, Apple, Google, Samsung, Facebook, AT\&T, Microsoft and Verizon vie for top spot in the world's most valuable companies $^{\mathrm{vi}}$ the books focus can seem partisan. The economic impact of these behemoths cannot be understated nor the influence socio-technical design too. The flowering of interactive design activity also founded on a strong material connection to technology that has accelerated the exponential rise of the design community from thousands to millions. At least if you search for 'designer 'on LinkedIn.

'Design Work' (Chapter 3) explores the 'everyday working practices' where practitioners 'function... symbolically...in the conditions of contemporary capitalism' (pp 37). The condition of the creative class is drawn primarily from Polaroid style accounts (e.g. Kimbell) that lack situational validity and qualitative depth you would expect from solid design research. Such ethnography would skim over the superficiality of service blueprints and instead uncover the modern incarnation of the creative means of production: The Mac. This partial dip into practice 'lite' ingresses into the mythical 'studio' that Julier describes and where the power of contemporary design is not just producing the abstract plans of liberal design futures, but instead builds out the pixels and scripts of product and service production.

The middle chapters outline the globalized context for design that we may be not so familiar with. I relished the journey through Turkey, India and China in chapters 4 on and 7 (Globalisation and 'Informal and Alternative Economies)' respectively. I found the later chapters on the public sector and IPR lacking, compared to the stronger, earlier sections. For the record, you cannot patent designs and Service Design's achievements could never have happened without Tory patronage. Period. 
While the devil is in the detail, Julier has opened a new and critically important window on design. The analysis just needs to go deeper and specifically account for real world practice. In such a case, the voices our community are not compromised by economic determinism but are greater than the sum of parts. Julier does not have a monopoly on conjuring causality out of theory to explain how design operates in the wider world. Others have pulled off similarly rare feats of illumination including Nardi's 'Context and Consciousness: Activity Theory and Human-computer Interaction' where an overarching theory shines light on contemporary design. With nearly 2500 citations it is also highly influential among practitioners too. Only time will tell if the Economies of Design has the audience and long-term intellectual traction to create a similar legacy as Cultures of Design. Economics is arguably a far broader and complex theoretical framework than relatively discrete areas of Soviet Psychology, Pragmatist Philosophy or Social Practice Theory. Let us not underestimate Julier's gift, this is a book that every academic, practitioner and maybe economist must read.

\section{References}

Ouelette, L and Hay, J. 2009. 'Makeover television, governmetality and the good citizen', in: Lewis, T. [ed], TV Transformations: Revealing the Makeover Show. London: Routledge. Pp $31-44$

\section{Notes on contributor}

John Knight is a doctoral student at Aalto University of Arts, Architecture and Design. Previously, he graduated from studying under Roy Ascott at Newport and then studied postgraduate design at Guildhall and Birmingham Institute of Art and Design under Jack Ingram. John is also a practicing Service Designer, working at Avanade's London Digital Studio.

\section{Address for correspondence}


john.knight@aalto.fi

Department of Design

Aalto University School of Arts, Design and Architecture

Otaniementie 14

02150 Espoo

Finland

\footnotetext{
${ }^{i}$ Dan Tapscott. 1997. Digital Economy: Promise and Peril in the Age of Networked Intelligence. McGraw-Hill Inc.,US

ii Taken from Alex Standish' review of Ralph Fevre's ,Individualism and Inequality: The Future of Work and Politics from Spiked-online. https://www.spiked-online.com/2017/01/27/the-neoliberal-individual/

iii See https://www.weforum.org/agenda/2018/01/embargoed-this-is-how-much-the-global-economy-will-growin-2018/

iv See Adage - 1980s Mergers and LBOS

https://adage.com/article/75-years-of-ideas/1980s-mergers-lbos/102706/

${ }^{v}$ Ben Elliot. 2002. Hiding behind the user - The Preoccupation with Usability in Web Design is a Cop-out https://www.spiked-online.com/2002/01/31/hiding-behind-the-user/

vi https://www.inc.com/.../amazon-google-most-valuable-brands-brand-finance-2018.html

vi Tim O'Reilly. 2005. What Is Web 2.0 Design Patterns and Business Models for the Next Generation of $\underline{\text { Software }}$
} 